\title{
Distance Learning: Effectiveness of an Interdisciplinary Course in Speech Pathology and Dentistry
}

\author{
Janine Santos Ramos, Letícia Korb da Silva, Arnaldo Pinzan, \\ Antonio de Castro Rodrigues and Giédre Berretin-Felix \\ Faculty of Dentistry of Bauru, University of São Paulo, \\ Bauru, São Paulo, Brazil
}

\author{
janinesramos@hotmail.com leticiakorb@usp.br \\ arnaldopinzan@gmail.com acastro@fob.usp.br gfelix@usp.br
}

\begin{abstract}
Objective: Evaluate the effectiveness of distance learning courses for the purpose of interdisciplinary continuing education in Speech Pathology and Dentistry. Methods: The online course was made available on the Moodle platform. A total of 30 undergraduates participated in the study (15 from the Dentistry course and 15 from the Speech Pathology course). Their knowledge was evaluated before and after the course, in addition to the user satisfaction by means of specific questionnaires. The course was evaluated by 6 specialists on the following aspects: presentation and quality of the content, audio-visual quality, adequacy to the target public, and information made available. To compare the obtained results in the pre- and post-course questionnaires, the test Wilcoxon was carried out, with a 5\% significance level. Results: the teaching/learning process, including the theoretical/practical application for the interdisciplinary training, proved to be effective as there was a statistically significant difference between the pre- and post- course evaluations ( $p<0.001)$, the users' satisfaction degree was favorable and the specialists evaluated the material as adequate regarding the target public, the audio-visual information quality and the strategies of content availability. Conclusion: The suggested distance-learning course proved to be effective for the purpose of Speech Pathology and Dentistry interdisciplinary education.
\end{abstract}

Keywords: Distance Learning, Speech, Language and Hearing Sciences, Dentistry, Interdisciplinary Research.

\section{Introduction}

Material published as part of this publication, either on-line or in print, is copyrighted by the Informing Science Institute. Permission to make digital or paper copy of part or all of these works for personal or classroom use is granted without fee provided that the copies are not made or distributed for profit or commercial advantage AND that copies 1) bear this notice in full and 2) give the full citation on the first page. It is permissible to abstract these works so long as credit is given. To copy in all other cases or to republish or to post on a server or to redistribute to lists requires specific permission and payment of a fee. Contact Publisher@InformingScience.org to request redistribution permission.

\section{Overview of Distance Learning}

The global improvement of the information and communication technology is an unquestionable reality, and people have more possibilities to access online sources every day. Based on this trend, the health field has the opportunity to 
increase its benefits, mainly on continuing the education of professionals.

Distance learning allows the student to study independently, according to his/her pace and spatiotemporal planning, and face-to-face meetings may occur offering opportunities for the socialization and the collaborative learning (Aretio, 2001).

Reports on distance learning are found in literature in the medicine field (Gardella, Guarin, \& Vive, 2003; Llambí et al., 2007; Pinto et al., 2008; VanLue et al., 2007) and, mainly, in the nursing field (Campbell, Gibson, Hall, Richards, \& Callery, 2008; Edwards, 2005; Holtslander, Racine, Furniss, Burles, \& Turner, 2012; Teles Filho \& Cassiani, 2008; Xelegati \& Evora, 2011). The quality of the service of tele-education and tele-assistance has been proved by different authors (Eskenazi, Martins, \& Ferreira, 2013; Hersh, Junium, Mailhot, \& Tidmarsh, 2001; Rafiq \& Merrell, 2005; Roine, Ohinmaa, \& Hailey, 2001; Shaikh, Lehmann, Kaleida, \& Cohen, 2008; Vucković et al., 2003); however, the cost-effectiveness relation still deserves investigation (Soirefmann, Blom, Leopoldo, \& Cestari, 2008).

In the nursing field, Teles Filho and Cassiani (2008) developed and evaluated a module on Medication Administration offered on a web-based virtual learning environment. The researchers used the Engagement Theory as a theoretical and methodological approach in the study carried out in two stages: the creation of the module and its evaluation by specialists. The instructional material had little amount of information on each screen and different font styles, sizes, and colors were used to highlight the contents. It also had images to ease the understanding and make the environment more attractive. The specialists (nurses, postgraduates, and professors) evaluated the material as to the content and informatics. They evaluated the module positively regarding the content distribution and accessibility, the use of images, and the explicitness and easiness to execute the program. So, the researchers concluded the module is appropriate to be used with students from the Nursing course.

Xelegati and Evora (2011) developed a virtual learning environment (VLE) for continuing training in order to manage and prevent adverse events in the nursing field. The authors used a threestage model, known as Computer Assisted Instruction (CAI), to develop the VLE. This model consists of exercise and practice, tutorial and simulation, as well as problem solving. The structure used for the VLE was the non-linear "interactive book" that encompasses some resources such as interactions of hypertexts, videos, sounds, static images, or animations. The authors initially identified the target public, chose the theme, and defined the objectives to be addressed, the resources available, and the instructional design. Then, the course was offered in five modules that consisted of contents, exercises, references, and supporting texts. They concluded that the development of a virtual learning environment addressing the management of adverse events will contribute to the awareness of nurses regarding the types of events, risk factors, classification, and incidence. However, a technical and content evaluation of the VLE is necessary to enable the use of the material in the continuing education of nurses in health institutions.

Regarding the distance learning in the medical field, Hersh, Junium, Mailhot and Tidmarsh (2001) developed and evaluated a distance learning course to be used in continuing education in medical informatics. The course was offered in the Blackboard Course info software as it presents a much simpler and consistent user's interface, which was compatible with the teaching modalities the authors planned on using. In addition to the course, the authors aimed at providing students with some parallel experiences through lectures, readings, and interaction among students and professors. The course resources consisted of online lectures that were developed by means of streaming audio plus slides in PowerPoint, discussion boards to promote the students interaction, and homework (multiple choice). A subject and different assignments were provided each week throughout the three-month course. Students were assessed by multiple-choice tests and a take-home final examination. They showed a strong satisfaction with the teaching modality, 
course content, and system performance. The authors observed the performance of distance learning students was superior to the performance of on-campus students and concluded that the course on medical informatics was successfully implemented by means of distance learning technologies, had a favorable satisfaction from students, and demonstrated learning.

Eskenazi, Martins, and Ferreira (2013) aimed at verifying the increase in knowledge and the counseling skills of students in the fifth year of a graduate course in medicine regarding the practice of oral health after a course of interactive tele-education. The study assessed 148 students that were divided into four groups (a control group and three others) that received progressive face to face and distance learning interventions. Only one of the groups was also in touch with specialists in oral health promotion. The knowledge increase was measured by a written test applied before and after the course. The authors observed the knowledge increase of the experimental groups was statistically superior to the control group and the performance of the group that was in touch with the specialists in oral health promotion was significantly superior to the other groups.

Based on the satisfactory results observed in the pioneering studies involving distance learning in the health field, it is relevant to consider that other areas can also benefit with this learning method. Therefore, the extension and application of distance learning courses in the other health fields will also contribute with the teaching and learning process.

\section{Distance Learning: Dentistry and Speech Pathology}

The growth of tele-dentistry has increased in the past years (Cartes-Velasquez \& Bustos-Leal, 2012), and the enforcement of distance learning in Dentistry can be exemplified by MEDICOL, a website whose goal is to be an addition to learning (Broudo \& Walsh, 2002), as well as by the development of an online atlas on Pediatric Dentistry with photos, illustrations, and x-rays, which has had a high level of users' approval. There is also a report on a distance learning pilot study in periodontics for graduate programs in European Countries. Such study used a virtual classroom, synchronous and asynchronous communication, in addition to the access to online libraries and multimedia material (Mattheos, Nattestad, Schittek, \& Attström, 2001). Since 2009, in the University of Missouri - Kansas City School of Dentistry, a faculty member teaches a hybrid online course (synchronous and asynchronous communication) with a highly specialized content in oral embryology and histology for students in dental hygiene and dentistry (Gadbury-Amyot, Singh, \& Overman, 2013). Distance learning specialization, update, and extension courses in Dentistry were found in Brazil (Masotti, Jardim, Oshima, \& Pacheco, 2002; Olival, Curvino, Faria, \& Groisman, 2008), as well as support material to undergraduate students (Skelton-Macedo et al., 2007).

In Speech Pathology, Smythe and Hughes (2008) studied the enrolled students' performance in an online program/course in basic human anatomy, which included online and face to face classes. The results showed the students' performances decreased whenever the themes were approached only online.

In audiology, Lieberth and Martin (2005) proved the efficiency of the use of a web-based puretone audiometry simulator by Speech Pathology undergraduate and graduate students. Inglês, Rojesky, and Branham (2000) developed a distance learning course for graduate students and speech pathology professionals, which approached the training of counseling skills in audiology provision services, and noticed that, despite the limitations related to the electronic instruction, the learning resembled that obtained in the conventional classroom. A study (Blasca, Maximino, Galdino, Campos, \& Picolini, 2010) evaluated a model of interactive tele-education for audiology teaching, and they concluded the educational material was effective in the teaching and learning process. 
Regarding the knowledge on voice, the Educational CD "The Voice: speech pathology and medicine" developed along with the Virtual Man Project of the Telemedicine Discipline, Universidade de São Paulo (USP), has information about the anatomy and physiology of voice and speech production, and it has demonstrated to be effective as an auto learning instrument to speech pathology and lyric singing students (Vieira, Berretin-Felix, \& Brasolotto, 2009).

By means of a literature review on tele-health in speech pathology, a study (Spinardi, Blasca, Wen, \& Maximino, 2009) noted the scarcity of publications aimed at distance learning as well as the centralization in the audiology field, showing the need to develop other projects, seeking the improvement of the services offered and the easiness to access them, generating a more effective impact on prevention, diagnosis and intervention of communication disorders.

There are no reports in literature about distance courses involving the interdisciplinary training or relation among health professionals.

\section{Significance of the Study and Purpose}

Among the different speech pathology specialties, there is the Orofacial Motricity, which approaches the disorders related to the stomatognathic system (Conselho Federal de Fonoaudiologia, 2006). Such alterations can be evidenced in dental cases, considering that functional abnormalities such as oral breathing, swallowing with tongue interposition, unilateral chewing, and orofacial muscle abnormal posture can be related to malocclusion (Yamaguchi \& Sueishi, 2003).

Since 2002, authors Jorge, Duque, Berretin-Félix, Costa, and Gomide have already suggested the importance of the performance of an interdisciplinary team, being constituted specially by pediatric dentists and speech audiologists, in the treatment of some deleterious oral habits in children as such habits may influence the development of the stomatognathic system.

Accordingly, these authors aimed to sensitize dentists and speech pathologists to the importance of the early intervention and the referrals that might be necessary in order to reestablish the orofacial functions and the muscle balance that might be altered due to deleterious oral habits.

Nobre, Gushiken, Periotto, and Araújo (2004) also referred to the importance of conducting longitudinal interdisciplinary studies, mainly in the performance between phonoaudiology and dentistry. The relation between form and function of the stomatognathic system was established as the authors frequently observed oral myofunctional disorders in mouth breathers with Angle Class II malocclusion.

The study carried out by Amaral, Bacha, Ghersel, and Rodrigues (2006) investigated the opinion of dental surgeons that are specialists in Orthodontics/Dentofacial Orthopedics and Pediatric Dentistry in addition to speech pathologists specialized in Orofacial Motricity. Unanimously, the researchers agreed on the need of interaction between the areas in order to avoid cases of orthodontic recurrences. The stomatognathic system is the common area for the performance of these professionals.

Other studies in literature have also confirmed the importance of the interdisciplinary performance between these two fields to favor a differential diagnosis and a better design of intervention in children (Verrastro et al., 2009) and even in the elderly (Dias \& Cardoso, 2009).

A more recent study (Silva \& Canto, 2014) reinforces the importance of the interdisciplinary work in all health fields, besides the focus on the association between dentistry and speech pathology. The interdisciplinary performance between speech pathologists, dentists, doctors, psychologists, physiotherapists, among others, promotes the improvement of therapies and treatments, a humanized and integrated care, which result in patients' satisfaction and health. The 
study also reinforces that such team work skills must be taught and learned since the academic life.

Given that the collaborative performance among health professionals has promoted quite favorable practical results (Benkert, 1997) and that experiences of computerized environments to support interdisciplinary teaching and clinical practice in Speech Pathology and Dentistry haven't been described, this study aims to evaluate the effectiveness of distance learning courses for a continuing interdisciplinary training in Speech Pathology and Dentistry, aiming not only at the best training for the professionals of the field, but also at bringing benefits to the patients from a better training for the professional that will serve them.

\section{Material and Methods}

\section{Ethical Aspects}

The Ethics Committee on Human Research of the Faculty of Dentistry of Bauru, Universidade de São Paulo (FOB / USP) approved the project, under the process N.101/2011. All participants were clearly informed about the study objectives and procedures, all of them read and signed the Consent Form.

\section{Study Participants}

Thirty students took the course and participated in the evaluation of this study teaching/learning process; they were 15 from the Dentistry course and 15 from the Speech Pathology course, officially enrolled in the eight term. They all had a six-month period to complete the course. Besides that, six specialists (three speech therapists and three dentists), with lato or stricto sensu postgraduation courses related to the interdisciplinary performance in Speech Pathology and Dentistry, were invited to carry out the technical and scientific evaluation of the course.

\section{Distance Course / Educational method}

The theoretical content was presented by means of an online course, approaching the following contents, which were developed in the Project "Distance Learning Proposal in the Speech Pathology and Dentistry Interdisciplinary Practice".

1 - Stomatognathic system anatomy

2 - Embryology, craniofacial growth and development

3 - Oral physiology and stomatognathic functions development

4 - Stomatognathic system evaluation;

5 - Orofacial myofunctional disorders: etiology, manifestations and treatment

6 - Interdisciplinary performance - clinical cases

Such contents were updated according to the literature review and submitted to an analysis by teachers and students related to the departments of Biological Science and Orthodontics, in addition to the Speech Pathology Department of the Bauru School of Dentistry - Universidade de São Paulo (FOB/USP).

Besides the theoretical content, a selection and update of illustrative images were performed in order to provide a more dynamic and attractive virtual environment, thus helping in the teaching/learning process. 
The material was shown in six modules, by means of Power Point, audio, text, image, and video classes. Evaluation instruments were also introduced to direct the students' progress in the teaching/learning process. It was standardized, adapting the design of the slides and texts according to the virtual environment template and made available on the Moodle (modular object-oriented dynamic learning environment) platform.

Moodle is a free software that supports learning, executed on a virtual environment. It is a learning platform designed to provide educators, administrators and learners with a single robust, secure and integrated system to create personalized learning environments. It is an evolving and active project based on the constructivist philosophy. Moodle has been designed to be fast and accessible, its interface is easy to navigate in desktops and mobile devices and it also has the possibility of customizing the site design and layout. It presents a personalized panel that allows the user to organize the exhibition of courses as desired and visualize current tasks and messages instantly. Moodle presents tools and collaborative activities such as forums, wikis, glossaries, database activities, assignments, calendar, chats and surveys. It has tools to handle files and a simple and intuitive text editor. It also permits doing and visualizing notifications, the progress of students, individually or as a group, as well as making detailed reports on students' activities and participation in the course and assessing through a questionnaire that can be edited as multiple choice, true or false, brief answer, etc. The questionnaire setting involves the definition of the period it will be available, an automatic feedback, varied assessment systems and the possibility of many attempts.

In this study, we chose to make available the contents of each module for 24 hours a day for a period of one month, so this was the time that the students had to accomplish each module. Thus they could take the course on time, in the place and hour of the day that they judge most appropriate. The course contained six modules and the students have six months to complete it. The course also used the "chat" tool in which students could communicate in real time with fellow students or administrators. They also had the option to leave messages with questions, which would later be answered if there were no online managers at the time of the question. This tool was used in order to ensure greater interactivity of the students.

The integration of audio features, videos, images, texts, and Power Points archives were also used in this course in order to provide a more attractive virtual environment, to be interesting, dynamic and pleasurable, to facilitate understanding of the content, and to complement the teachinglearning process.

\section{Evaluation of the Program's Effectiveness}

\section{Assessment of students' knowledge}

Students underwent cognitive skills evaluation, before and after taking the online course, by means of specific questionnaires. Both questionnaires (before and after the course) involved the evaluation of the same type of knowledge by presenting the questions in a different way or order from the way it was initially presented. Each questionnaire consisted of 13 multiple choice questions about aspects related to embryonic processes, development of stomatognathic structures since birth, identification of structures in oral and/or oronasal cavities, concepts of cephalometry, concepts related to the function during occlusal movements, definition of some terms, clinical case related to the performance between dentistry and speech pathology, malocclusion installation causes, deleterious oral habits, speech, swallowing and chewing problems, questions involving the relation between the swallowing function with changes and the mouth breathing, Class II malocclusion, inadequate head posture, changes in orofacial sensitivity, tonus or mobility, functional and structural aspects of the stomatognathic system, and process of a speech pathology diagnosis. 
As a criterion aimed at evaluating the effectiveness of the program in relation to the cognitive skills, a comparison was carried out between the numbers of correct answers regarding the questions that were relevant to the theoretical contents presented in the online course, looking for statistically significant differences between both analyzed periods.

\section{Evaluation of students' perception}

Each module was individually evaluated by a poll made of 7 questions (Appendix) to be answered by each student at the end of the activity. Such questionnaires addressed the following aspects: contribution to the training; quality of the contents presented; quality of the illustrations presented, amount of contents presented; complexity level of the dentistry content presented; complexity level of the speech pathology content presented; access to navigation on the virtual learning environment. In addition to that, at the end of the poll, the students had the opportunity to criticize, suggest, or comment on the module being analyzed.

\section{Evaluation of specialists' perception}

In a period of 30 days, the specialists were asked to access and analyze the course, as well as to fill in the evaluation protocol suggested by Spinardi (2009), which evaluates the presentation and quality of the content, audiovisual quality, adequacy to target public, and information available.

\section{Statistical Methods}

The comparison between the results obtained in the pre- and post-course questionnaires was carried out with the administration of the Wilcoxon test, considering the significance level of 5\% $(\mathrm{p}<0.05)$. The comparison between the modules regarding the user's satisfaction was carried with the administration of the Kruskal-Wallis test, considering the significance level of $5 \%(\mathrm{p}<0.05)$.

\section{Results}

The results will be described in two steps: the course development process and the course effectiveness evaluation.

\section{Development Process of the Interdisciplinary Course in Speech Pathology and Dentistry}

According to the obtained results, we can see (Table 1) that the only content which did not need modification was the anatomy content. However, the other modules needed an update in the complementary texts, files, and images. Such contents were made available on the Moodle platform, presented in six modules, in classes with PowerPoint, audio, pdf texts, and videos. 
Table 1 - List of updated materials and the type of file provided module by module.

\begin{tabular}{|c|c|c|}
\hline MODULE & Type of file provided & Updates/Modifications \\
\hline 1 Stomatognathic system anatomy & $\begin{array}{l}\text { PowerPoints, audios and } \\
\text { texts. }\end{array}$ & No modification required \\
\hline $\begin{array}{l}2 \text { Embryology, Craniofacial growth and } \\
\text { development }\end{array}$ & $\begin{array}{l}\text { PowerPoint, texts and } \\
\text { images }\end{array}$ & Update the text and images \\
\hline $\begin{array}{l}3 \text { Oral Physiology and Stomatognathic } \\
\text { functions development }\end{array}$ & Text with images & $\begin{array}{l}\text { Update the text and inserting im- } \\
\text { ages }\end{array}$ \\
\hline 4 Stomatognathic System Evaluation & $\begin{array}{l}\text { PowerPoints and texts } \\
\text { with images. }\end{array}$ & $\begin{array}{l}\text { Update the text, images and the } \\
\text { PowerPoint file. }\end{array}$ \\
\hline $\begin{array}{l}5 \text { Orofacial myofunctional disorders: } \\
\text { etiology, manifestations and treatment }\end{array}$ & Texts with images & Update the text and images \\
\hline $\begin{array}{l}6 \text { Interdisciplinary Performance - Clini- } \\
\text { cal Cases }\end{array}$ & $\begin{array}{l}\text { Texts, images and } \\
\text { videos }\end{array}$ & Update the text \\
\hline
\end{tabular}

\section{Effectiveness Evaluation of the Speech Pathology and Dentistry} Interdisciplinary Course

\section{Cognitive Skills}

The evaluation of the student's performance, which reflects the effectiveness of the course in relation to the teaching/learning process, was carried out by means of the administration of the Wilcoxon test to compare the number of correct answers obtained in the pre- and post-course evaluation questionnaire (Table 2).

Table 2 - Presentation of the number of correct answers obtained in the evaluation questionnaire administered before and after the completion of the Speech Pathology and Dentistry interdisciplinary course.

\begin{tabular}{cccc}
\hline & Correct answers before course & Correct answers after course & p-value \\
\hline Minimum & 3.0 & 5.0 & \\
Maximum & 10.0 & 13.0 & $<0.001$ \\
Median & 7.000 & 8.000 & 8.4 \\
Average & 7.0 & \pm 2.5 \\
Standard Deviation & \pm 1.7 & & \\
\hline
\end{tabular}

The results showed there is difference, statistically significant, between the pre- and post-course evaluations $(\mathrm{p}<0,001)$, pointing out that the material promoted the students' effective learning.

\section{Users perception / satisfaction degree}

The poll has shown the students' satisfaction degree in different aspects module by module. Generally, it was observed that the different modules were well evaluated. It was possible to notice that regarding the contribution for training, the illustration quality, and the presented contents, as 
well as the access and navigation on the virtual learning environment, for most students, the evaluation varied between excellent, very good, and good.

Similarly, the satisfaction degree of users who considered the complexity level of the dentistry and speech pathology content adequate varied from 89 to $96 \%$ (dentistry content) and 91 to $96 \%$ (speech pathology content).

Analyzing the open question, we can see that the modules obtained higher amounts of positive comments than negative comments, as illustrated in Figure 1.

\begin{tabular}{|c|c|c|c|c|}
\hline & Positive comments & $\begin{array}{l}\% \text { and } N \text { of } \\
\text { comments }\end{array}$ & Negative comments & $N^{0}$ of comments \\
\hline 1st Module & $\begin{array}{l}\text { The module was inter- } \\
\text { esting and it served as a } \\
\text { review of anatomy } \\
\text { mainly. }\end{array}$ & $19,23 \%(n=25)$ & $\begin{array}{l}\text { This module was a bit } \\
\text { lengthy, demanding too } \\
\text { much time for reading } \\
\text { texts. }\end{array}$ & $25,49 \%(n=13)$ \\
\hline 2nd Module & $\begin{array}{l}\text { This module content } \\
\text { was presented in an } \\
\text { objective and straight- } \\
\text { forward manner, it con- } \\
\text { tained the necessary } \\
\text { information. }\end{array}$ & $15,38 \%(n=20)$ & $\begin{array}{l}\text { Could have more illustra- } \\
\text { tions to exemplify. }\end{array}$ & $11,76 \%(n=6)$ \\
\hline 3rd Module & $\begin{array}{l}\text { Excellent material for } \\
\text { study and review. }\end{array}$ & $13,85 \%(n=18)$ & $\begin{array}{l}\text { This module showed an } \\
\text { extensive content but } \\
\text { very relevant. }\end{array}$ & $11,76 \%(n=6)$ \\
\hline 4th Module & $\begin{array}{l}\text { I like a lot these speech } \\
\text { therapy issues related to } \\
\text { orthodontics. I think it } \\
\text { is a very important } \\
\text { integration! }\end{array}$ & $16,15 \%(n=21)$ & $\begin{array}{l}\text { This module was the } \\
\text { most tiring so far. Pre- } \\
\text { sents many lessons. }\end{array}$ & $21,57 \%(n=11)$ \\
\hline 5 Module & $\begin{array}{l}\text { Module was very inter- } \\
\text { esting and related the } \\
\text { areas of dentistry and } \\
\text { speech therapy. }\end{array}$ & $18,46 \%(n=24)$ & $\begin{array}{l}\text { The texts are still exten- } \\
\text { sive. }\end{array}$ & $11,76 \%(n=6)$ \\
\hline 6 Module & $\begin{array}{l}\text { The module is presented } \\
\text { in an interesting and } \\
\text { interactive way due to } \\
\text { the presentation of clin- } \\
\text { ical cases. }\end{array}$ & $16,92 \%(n=22)$ & $\begin{array}{l}\text { Could there be a greater } \\
\text { number of clinical cases } \\
\text { to illustrate the multidis- } \\
\text { ciplinary treatment. }\end{array}$ & $17,65 \%(\mathrm{n}=9)$ \\
\hline $\begin{array}{l}\text { Total of } \\
\text { comments }\end{array}$ & - & $100 \%(n=130)$ & - & $100 \%(\mathrm{n}=51)$ \\
\hline
\end{tabular}

Figure 1 - Main positive, negative and number of comments ( $n^{0}$ of comments) reported by the students in each module.

In Tables 3 to 5, it is possible to note, with more details, the students' opinions when evaluating, in each module, the aforementioned aspects. The highlighted cells represent the concept that showed more answers. 
Distance learning: Effectiveness of an interdisciplinary course in speech pathology and dentistry

Table 3 - The users' satisfaction degree as to the contribution for the training; quality of the content presented; quality of the illustrations presented, and access and navigation on virtual learning environment.

\begin{tabular}{|c|c|c|c|c|c|c|c|c|c|c|}
\hline \multirow[b]{2}{*}{ Module } & & \multicolumn{5}{|c|}{ Satisfaction Degree } & \multirow[b]{2}{*}{ Median } & \multirow[b]{2}{*}{$\begin{array}{c}\text { First } \\
\text { Quartile }\end{array}$} & \multirow[b]{2}{*}{$\begin{array}{c}\text { Third } \\
\text { Quartile }\end{array}$} & \multirow[b]{2}{*}{ p value } \\
\hline & & Excellent & $\begin{array}{l}\text { Very } \\
\text { Good }\end{array}$ & Good & Fair & Poor & & & & \\
\hline \multirow{7}{*}{$\begin{array}{c}\text { Contribution } \\
\text { for the } \\
\text { training }\end{array}$} & 1 & $36 \%(n=20)$ & $\begin{array}{c}32 \% \\
(\mathrm{n}=18)\end{array}$ & $\begin{array}{c}30 \% \\
(n=17)\end{array}$ & $\begin{array}{c}2 \% \\
(\mathrm{n}=1)\end{array}$ & $\begin{array}{c}0 \% \\
(\mathrm{n}=0)\end{array}$ & 4.000 & 3.000 & 5.000 & \\
\hline & 2 & $36 \%(n=20)$ & $\begin{array}{c}32 \% \\
(\mathrm{n}=18)\end{array}$ & $\begin{array}{c}30 \% \\
(n=17)\end{array}$ & $\begin{array}{c}2 \% \\
(n=1)\end{array}$ & $\begin{array}{c}0 \% \\
(\mathrm{n}=0)\end{array}$ & 4.000 & 3.000 & 5.000 & \\
\hline & 3 & $37 \%(n=21)$ & $\begin{array}{c}28 \% \\
(\mathrm{n}=16)\end{array}$ & $\begin{array}{c}33 \% \\
(n=19)\end{array}$ & $\begin{array}{c}2 \% \\
(n=1)\end{array}$ & $\begin{array}{c}0 \% \\
(n=0)\end{array}$ & 4.000 & 3.000 & 5.000 & \\
\hline & 4 & $32 \%(n=17)$ & $\begin{array}{c}34 \% \\
(\mathrm{n}=18)\end{array}$ & $\begin{array}{c}34 \% \\
(n=18)\end{array}$ & $\begin{array}{c}0 \% \\
(\mathrm{n}=0)\end{array}$ & $\begin{array}{c}0 \% \\
(\mathrm{n}=0)\end{array}$ & 4.000 & 3.000 & 5.000 & \\
\hline & 5 & $35 \%(n=18)$ & $\begin{array}{c}29 \% \\
(\mathrm{n}=15)\end{array}$ & $\begin{array}{c}37 \% \\
(n=19)\end{array}$ & $\begin{array}{c}0 \% \\
(\mathrm{n}=0)\end{array}$ & $\begin{array}{c}0 \% \\
(\mathrm{n}=0)\end{array}$ & 4.000 & 3.000 & 5.000 & \\
\hline & 6 & $38 \%(n=20)$ & $\begin{array}{c}28 \% \\
(\mathrm{n}=14) \\
\end{array}$ & $\begin{array}{c}30 \% \\
(n=16) \\
\end{array}$ & $\begin{array}{c}4 \% \\
(n=2) \\
\end{array}$ & $\begin{array}{c}2 \% \\
(n=1)\end{array}$ & 4.000 & 3.000 & 5.000 & \\
\hline & & & & & & & & & & 0,999 \\
\hline \multirow{7}{*}{$\begin{array}{l}\text { Quality of } \\
\text { the content } \\
\text { presented }\end{array}$} & 1 & $38 \%(\mathrm{n}=21)$ & $\begin{array}{c}34 \% \\
(\mathrm{n}=19)\end{array}$ & $\begin{array}{c}29 \% \\
(\mathrm{n}=16)\end{array}$ & $\begin{array}{c}0 \% \\
(\mathrm{n}=0)\end{array}$ & $\begin{array}{c}0 \% \\
(\mathrm{n}=0)\end{array}$ & 4.000 & 3.000 & 5.000 & \\
\hline & 2 & $38 \%(n=21)$ & $\begin{array}{c}34 \% \\
(\mathrm{n}=19)\end{array}$ & $\begin{array}{c}29 \% \\
(n=16)\end{array}$ & $\begin{array}{c}0 \% \\
(\mathrm{n}=0)\end{array}$ & $\begin{array}{c}0 \% \\
(\mathrm{n}=0)\end{array}$ & 4.000 & 3.000 & 5.000 & \\
\hline & 3 & $30 \%(n=17)$ & $\begin{array}{c}35 \% \\
(\mathrm{n}=20)\end{array}$ & $\begin{array}{c}33 \% \\
(n=19)\end{array}$ & $\begin{array}{c}2 \% \\
(\mathrm{n}=1)\end{array}$ & $\begin{array}{c}0 \% \\
(\mathrm{n}=0)\end{array}$ & 4.000 & 3.000 & 5.000 & \\
\hline & 4 & $34 \%(n=18)$ & $\begin{array}{c}30 \% \\
(\mathrm{n}=16)\end{array}$ & $\begin{array}{c}32 \% \\
(n=17)\end{array}$ & $\begin{array}{c}4 \% \\
(n=2)\end{array}$ & $\begin{array}{c}0 \% \\
(\mathrm{n}=0)\end{array}$ & 4.000 & 3.000 & 5.000 & \\
\hline & 5 & $31 \%(n=16)$ & $\begin{array}{c}35 \% \\
(\mathrm{n}=18)\end{array}$ & $\begin{array}{c}35 \% \\
(n=18)\end{array}$ & $\begin{array}{c}0 \% \\
(\mathrm{n}=0)\end{array}$ & $\begin{array}{c}0 \% \\
(\mathrm{n}=0)\end{array}$ & 4.000 & 3.000 & 5.000 & \\
\hline & 6 & $34 \%(n=18)$ & $\begin{array}{c}26 \% \\
(n=14)\end{array}$ & $\begin{array}{c}34 \% \\
(n=18)\end{array}$ & $\begin{array}{c}4 \% \\
(n=2)\end{array}$ & $\begin{array}{c}2 \% \\
(\mathrm{n}=1)\end{array}$ & 4.000 & 3.000 & 5.000 & \\
\hline & & & & & & & & & & 0,803 \\
\hline \multirow{7}{*}{$\begin{array}{l}\text { Quality of } \\
\text { the illustra- } \\
\text { tions pre- } \\
\text { sented }\end{array}$} & 1 & $25 \%(n=14)$ & $\begin{array}{c}45 \% \\
(\mathrm{n}=25)\end{array}$ & $\begin{array}{c}27 \% \\
(n=15)\end{array}$ & $\begin{array}{c}4 \% \\
(n=2)\end{array}$ & $\begin{array}{c}0 \% \\
(\mathrm{n}=0)\end{array}$ & 4.000 & 3.000 & 4.750 & \\
\hline & 2 & $25 \%(n=14)$ & $\begin{array}{c}45 \% \\
(\mathrm{n}=25)\end{array}$ & $\begin{array}{c}27 \% \\
(n=15)\end{array}$ & $\begin{array}{c}4 \% \\
(n=2)\end{array}$ & $\begin{array}{c}0 \% \\
(\mathrm{n}=0)\end{array}$ & 4.000 & 3.000 & 4.750 & \\
\hline & 3 & $32 \%(n=18)$ & $\begin{array}{c}23 \% \\
(n=13)\end{array}$ & $\begin{array}{c}40 \% \\
(n=23)\end{array}$ & $\begin{array}{c}5 \% \\
(n=3)\end{array}$ & $\begin{array}{c}0 \% \\
(\mathrm{n}=0)\end{array}$ & 4.000 & 3.000 & 5.000 & \\
\hline & 4 & $28 \%(n=15)$ & $\begin{array}{c}28 \% \\
(n=15)\end{array}$ & $\begin{array}{c}30 \% \\
(n=19)\end{array}$ & $\begin{array}{c}4 \% \\
(n=2)\end{array}$ & $\begin{array}{c}4 \% \\
(n=2)\end{array}$ & 4.000 & 3.000 & 5.000 & \\
\hline & 5 & $27 \%(n=14)$ & $\begin{array}{c}31 \% \\
(n=16)\end{array}$ & $\begin{array}{c}37 \% \\
(n=19)\end{array}$ & $\begin{array}{c}4 \% \\
(n=2)\end{array}$ & $\begin{array}{c}2 \% \\
(n=1)\end{array}$ & 4.000 & 3.000 & 5.000 & \\
\hline & 6 & $38 \%(n=20)$ & $\begin{array}{c}19 \% \\
(\mathrm{n}=10)\end{array}$ & $\begin{array}{c}43 \% \\
(n=23)\end{array}$ & $\begin{array}{c}0 \% \\
(\mathrm{n}=0)\end{array}$ & $\begin{array}{c}0 \% \\
(\mathrm{n}=0)\end{array}$ & 4.000 & 3.000 & 5.000 & \\
\hline & & & & & & & & & & 0,895 \\
\hline \multirow{7}{*}{$\begin{array}{l}\text { Access and } \\
\text { navigation }\end{array}$} & 1 & $32 \%(n=18)$ & $\begin{array}{c}36 \% \\
(\mathrm{n}=20)\end{array}$ & $\begin{array}{c}29 \% \\
(\mathrm{n}=16)\end{array}$ & $\begin{array}{c}4 \% \\
(n=2)\end{array}$ & $\begin{array}{c}0 \% \\
(\mathrm{n}=0)\end{array}$ & 4.000 & 3.000 & 5.000 & \\
\hline & 2 & $32 \%(n=18)$ & $\begin{array}{c}36 \% \\
(\mathrm{n}=20)\end{array}$ & $\begin{array}{c}39 \% \\
(n=16)\end{array}$ & $\begin{array}{c}4 \% \\
(n=2)\end{array}$ & $\begin{array}{c}0 \% \\
(n=0)\end{array}$ & 4.000 & 3.000 & 5.000 & \\
\hline & 3 & $33 \%(n=19)$ & $\begin{array}{c}32 \% \\
(n=18)\end{array}$ & $\begin{array}{c}32 \% \\
(n=18)\end{array}$ & $\begin{array}{c}4 \% \\
(n=2)\end{array}$ & $\begin{array}{c}0 \% \\
(\mathrm{n}=0)\end{array}$ & 4.000 & 3.000 & 5.000 & \\
\hline & 4 & $25 \%(n=13)$ & $\begin{array}{c}34 \% \\
(\mathrm{n}=18)\end{array}$ & $\begin{array}{c}40 \% \\
(n=21)\end{array}$ & $\begin{array}{c}2 \% \\
(n=1)\end{array}$ & $\begin{array}{c}0 \% \\
(\mathrm{n}=0)\end{array}$ & 4.000 & 3.000 & 4.500 & \\
\hline & 5 & $27 \%(n=14)$ & $\begin{array}{c}31 \% \\
(\mathrm{n}=16)\end{array}$ & $\begin{array}{c}38 \% \\
(\mathrm{n}=20)\end{array}$ & $\begin{array}{c}4 \% \\
(n=2)\end{array}$ & $\begin{array}{c}0 \% \\
(\mathrm{n}=0)\end{array}$ & 4.000 & 3.000 & 5.000 & \\
\hline & 6 & $28 \%(n=15)$ & $\begin{array}{c}40 \% \\
(\mathrm{n}=21)\end{array}$ & $\begin{array}{c}30 \% \\
(n=16)\end{array}$ & $\begin{array}{c}2 \% \\
(\mathrm{n}=1)\end{array}$ & $\begin{array}{c}0 \% \\
(\mathrm{n}=0)\end{array}$ & 4.000 & 3.000 & 5.000 & \\
\hline & & & & & & & & & & 0,809 \\
\hline
\end{tabular}


Table 4 - Users' satisfaction degree as the amount of content presented

\begin{tabular}{|c|c|c|c|c|c|c|c|c|}
\hline & Module & Sufficient & Insufficient & Excessive & Median & $\begin{array}{c}\text { First } \\
\text { Quartile }\end{array}$ & $\begin{array}{c}\text { Third } \\
\text { Quartile }\end{array}$ & $\begin{array}{c}\mathbf{p} \\
\text { value }\end{array}$ \\
\hline \multirow{6}{*}{$\begin{array}{c}\text { Amount } \\
\text { of } \\
\text { content } \\
\text { presented }\end{array}$} & 1 & $\begin{array}{c}96 \% \\
(n=54)\end{array}$ & $0 \%(\mathrm{n}=0)$ & $4 \%(n=2)$ & 3.000 & 3.000 & 3.000 & \\
\hline & 2 & $\begin{array}{c}96 \% \\
(\mathrm{n}=54)\end{array}$ & $0 \%(\mathrm{n}=0)$ & $4 \%(n=2)$ & 3.000 & 3.000 & 3.000 & \\
\hline & 3 & $\begin{array}{c}88 \% \\
(\mathrm{n}=50)\end{array}$ & $5 \%(n=3)$ & $7 \%(n=4)$ & 3.000 & 3.000 & 3.000 & \\
\hline & 4 & $\begin{array}{c}83 \% \\
(\mathrm{n}=44)\end{array}$ & $2 \%(n=1)$ & $\begin{array}{c}15 \% \\
(\mathrm{n}=8)\end{array}$ & 3.000 & 3.000 & 3.000 & \\
\hline & 5 & $\begin{array}{c}88 \% \\
(n=46)\end{array}$ & $0 \%(n=0)$ & $\begin{array}{c}12 \% \\
(\mathrm{n}=6)\end{array}$ & 3.000 & 3.000 & 3.000 & \\
\hline & 6 & $\begin{array}{c}89 \% \\
(n=47)\end{array}$ & $7 \%(n=4)$ & $4 \%(n=2)$ & 3.000 & 3.000 & 3.000 & \\
\hline
\end{tabular}

Table 5 - Users' satisfaction degree as to the level of complexity of the dentistry and speech pathology contents.

\begin{tabular}{|c|c|c|c|c|c|c|c|c|}
\hline & Module & Adequate & $\begin{array}{c}\text { Little } \\
\text { complex }\end{array}$ & $\begin{array}{c}\text { Very } \\
\text { Complex }\end{array}$ & Median & $\begin{array}{c}\text { First } \\
\text { Quartile }\end{array}$ & $\begin{array}{c}\text { Third } \\
\text { Quartile }\end{array}$ & $\begin{array}{c}\mathbf{p} \\
\text { value }\end{array}$ \\
\hline \multirow{7}{*}{$\begin{array}{c}\text { Dentistry } \\
\text { content }\end{array}$} & 1 & $\begin{array}{c}89 \% \\
(n=50)\end{array}$ & $\begin{array}{c}7 \% \\
(n=4)\end{array}$ & $4 \%(n=2)$ & 3.000 & 3.000 & 3.000 & \\
\hline & 2 & $\begin{array}{c}89 \% \\
(n=50)\end{array}$ & $\begin{array}{c}7 \% \\
(n=4)\end{array}$ & $4 \%(n=2)$ & 3.000 & 3.000 & 3.000 & \\
\hline & 3 & $\begin{array}{c}93 \% \\
(n=53)\end{array}$ & $\begin{array}{c}2 \% \\
(n=1)\end{array}$ & $5 \%(n=3)$ & 3.000 & 3.000 & 3.000 & \\
\hline & 4 & $\begin{array}{c}89 \% \\
(n=46)\end{array}$ & $\begin{array}{c}2 \% \\
(n=1)\end{array}$ & $9 \%(n=5)$ & 3.000 & 3.000 & 3.000 & \\
\hline & 5 & $\begin{array}{c}96 \% \\
(n=50)\end{array}$ & $\begin{array}{c}2 \% \\
(n=1)\end{array}$ & $2 \%(n=1)$ & 3.000 & 3.000 & 3.000 & \\
\hline & 6 & $\begin{array}{c}94 \% \\
(n=50)\end{array}$ & $\begin{array}{c}4 \% \\
(n=2)\end{array}$ & $2 \%(n=1)$ & 3.000 & 3.000 & 3.000 & \\
\hline & & & & & & & & 0,614 \\
\hline \multirow{6}{*}{$\begin{array}{l}\text { Speech } \\
\text { pathology } \\
\text { content }\end{array}$} & 1 & $\begin{array}{c}96 \% \\
(n=54)\end{array}$ & $\begin{array}{c}2 \% \\
(n=1)\end{array}$ & $2 \%(n=1)$ & 3.000 & 3.000 & 3.000 & \\
\hline & 2 & $\begin{array}{c}96 \% \\
(n=54)\end{array}$ & $\begin{array}{c}2 \% \\
(n=1)\end{array}$ & $2 \%(n=1)$ & 3.000 & 3.000 & 3.000 & \\
\hline & 3 & $\begin{array}{c}91 \% \\
(n=52)\end{array}$ & $\begin{array}{c}0 \% \\
(n=0)\end{array}$ & $9 \%(n=5)$ & 3.000 & 3.000 & 3.000 & \\
\hline & 4 & $\begin{array}{c}94 \% \\
(n=50)\end{array}$ & $\begin{array}{c}0 \% \\
(\mathrm{n}=0)\end{array}$ & $6 \%(n=3)$ & 3.000 & 3.000 & 3.000 & \\
\hline & 5 & $\begin{array}{c}94 \% \\
(n=49)\end{array}$ & $\begin{array}{c}0 \% \\
(n=0)\end{array}$ & $6 \%(n=3)$ & 3.000 & 3.000 & 3.000 & \\
\hline & 6 & $\begin{array}{c}94 \% \\
(n=50)\end{array}$ & $\begin{array}{c}2 \% \\
(n=1)\end{array}$ & $4 \%(n=2)$ & 3.000 & 3.000 & 3.000 & \\
\hline
\end{tabular}




\section{Technical and scientific quality}

We will show below the results obtained through the evaluation of specialists for the following aspects according to the questions of the evaluation protocol: presentation and quality of the content, audiovisual quality, adequacy to target public, and information available.

The first question evaluated the aspects related to the content presentation and quality through the following items: scope, vocabulary, instructional sequence of topics, and way of presenting the concept. The values attributed by the specialists are in Table 6 .

Table 6 - Specialists' satisfaction degree related to the content presentation and quality.

\begin{tabular}{lcccccccc}
\hline & \multicolumn{2}{c}{ Scope } & \multicolumn{2}{c}{ Vocabulary } & \multicolumn{2}{c}{$\begin{array}{c}\text { Instructional } \\
\text { sequence of topics }\end{array}$} & \multicolumn{2}{c}{$\begin{array}{c}\text { Way of concept } \\
\text { presentation }\end{array}$} \\
\hline & $\mathrm{N}$ & $\%$ & $\mathrm{~N}$ & $\%$ & $\mathrm{~N}$ & $\%$ & $\mathrm{n}$ & $\%$ \\
\hline Excellent & 5 & 83.33 & 5 & 83.33 & 5 & 83.33 & 4 & 66.67 \\
Satisfactory & 1 & 16.67 & 1 & 16.67 & 1 & 16.67 & 1 & 16.67 \\
Reasonable & - & - & - & - & - & - & 1 & 16.67 \\
Unsatisfactory & - & - & - & - & - & - & - & - \\
\hline
\end{tabular}

Additionally, the main criticism made (cited by two specialists) through the open question, when evaluating the content presentation and quality, was related to the absence of commands to forward, rewind, or skip classes, which hinders the progress of the class. Two experts also suggested the standardization of the content presentation of the modules.

The second question assessed the aspects related to the audiovisual quality through the items: quality of the pictures, quality of the videos, and quality of the animations. The evaluation results can be observed in Table 7.

Table 7 - Specialists' satisfaction degree related to the audiovisual quality.

\begin{tabular}{lcccccc}
\hline & \multicolumn{2}{c}{ Quality of the pictures } & \multicolumn{2}{c}{ Quality of the videos } & \multicolumn{2}{c}{$\begin{array}{c}\text { Quality of the } \\
\text { animations }\end{array}$} \\
\hline & $\mathrm{N}$ & $\%$ & $\mathrm{n}$ & $\%$ & $\mathrm{n}$ & $\%$ \\
\hline Excellent & 1 & 16.67 & 2 & 33.33 & 2 & 33.33 \\
Satisfactory & 4 & 66.67 & 2 & 33.33 & 3 & 50 \\
Reasonable & 1 & 16.67 & - & - & - & - \\
Unsatisfactory & - & - & 2 & 33.33 & 1 & 16.67 \\
\hline
\end{tabular}

Three of the specialists reported that some classes were too long or had too much written content (one cited the PDF files part of module 1) and suggested that a greater amount of illustrative figures and dynamic images should be inserted in these classes.

Three specialists reported it was not possible to access some videos that were available in the course, hampering the evaluation process. Given that such criticism was not mentioned by the other three evaluators or by the students, it is possible that it was probably a problem regarding the personal software of each evaluator.

Question three evaluated the adequacy of the content to the target public and obtained $100 \%$ positive responses (adequate). Therefore, all specialists considered the material appropriate to the target public.

Finally, the fourth question assessed aspects related to the information available, regarding reliability, update, research sources, and spelling and grammar. The values attributed by the experts are in Table 8. 
Ramos, Silva, Pinzan, Rodrigues, \& Berretin-Felix

Table 8 - Specialists' satisfaction degree related to the information available.

\begin{tabular}{lcccccccc}
\hline & \multicolumn{2}{c}{$\begin{array}{l}\text { Regarding } \\
\text { reliability }\end{array}$} & \multicolumn{2}{c}{ Update } & \multicolumn{2}{c}{ Research sources } & \multicolumn{2}{c}{$\begin{array}{c}\text { Spelling and } \\
\text { gramar }\end{array}$} \\
\hline & $\mathrm{N}$ & $\%$ & $\mathrm{n}$ & $\%$ & $\mathrm{~N}$ & $\%$ & $\mathrm{~N}$ & $\%$ \\
\hline Excellent & 6 & 100 & 4 & 66.67 & 3 & 50 & 4 & 66.67 \\
Satisfactory & - & - & 2 & 33.33 & 1 & 16.67 & 2 & 33.33 \\
Reasonable & - & - & - & - & 2 & 33.33 & - & - \\
Unsatisfactory & - & - & - & - & - & - & - & - \\
\hline
\end{tabular}

Therefore, according to the specialists, the course can be considered from excellent to satisfactory, and regarding the criticism and suggestions exemplified above, we observed a higher number of positive (23) than negative (13) comments.

\section{Discussion}

Distance learning aims, not only to reduce physical and temporal distance, but also to increase the appreciation of "learning to learn", enabling the students to acquire knowledge while respecting their own rhythm of study, their time, and their personal characteristics (Spinardi, 2009).

Actions directed to this training modality are found in some areas of health, especially in nursing (Campbell et al., 2008; Edwards, 2005; Holtslander et al., 2012; Teles Filho \& Cassiani, 2008; Xelegati \& Evora, 2011), and in some specialties of medicine (Gardella et al., 2003; Llambí et al., 2007; Pinto et al., 2008; VanLue et al., 2007).

However, there are studies in literature that describe learning tools similar to the ones proposed in this study that involve the interdisciplinary training in speech pathology and dentistry practice, favoring the performance in a collaborative manner among health professionals, enabling the achievement of quite favorable practical results (Benkert, 1997).

The tool used for the development of the distance learning course was the Moodle platform. The Moodle environment was chosen because it presents the main features of a virtual learning environment (VLE), that is, tools that allow doing assessments, opinion polls, questionnaires, and chat rooms, thereby ensuring interactivity, integration of resources, learning services, and communication (Bollela, Grec, \& Matias, 2009; Martins \& Campestrini, 2004). Literature shows the importance of virtual environments providing the learning, creation, development, and management of Web courses (Ribeiro \& Lopes, 2006; Telles Filho \& Cassiani, 2008).

The resources provided by Moodle reached the needs requested and, although some specialists found some difficulty to access the videos, in the open question the students did not criticize the working of the virtual environment. Moreover, the users' satisfaction degree as to the access and navigation in the virtual learning environment varied between the concepts excellent, very good, and good, proving it to be also an appropriate instrument for students.

In the present study, it was possible to find a statistically significant difference between the preand post-course evaluations performed by the students, demonstrating the effectiveness of this material as an educational tool. We can compare these results to studies (Blasca \& Bevilacqua, 2003; Ribeiro \& Lopes, 2006) that also verified an improvement in the students' accomplishment by the application of pre- and post-test questionnaires, with favorable results as to the students learning.

The students who participated in this research expressed satisfaction about the general quality of the course, as well as about the use of distance learning. According to Kemczinski, Bringhenti, Castro, and Heinneck (2000), to evaluate the students' satisfaction (target public of the study) it is essential to verify their level of satisfaction in relation to aspects of classroom environment or- 
ganization, didactic aspects, self-assessment, the performance of those organizing and monitoring the course, as well as the technical staff.

Most comments were positive. For example, Module 1 was considered interesting and served as a review for the anatomy content. Module 2 was praised for presenting the content in a simple and objective way with the necessary information. Module 3 was described as having an excellent content to review and study. In Modules 4 and 5, the interdisciplinary aspect was praised and the content was found to be interesting. Finally, the format of Module 6, which was of an "interactive book" to present clinical cases, was considered adequate.

Regarding the negative comments, most of the opinions were basically related to the excess of content in Module 1, lack of figures in Module 2, and extensive, but relevant, content in Module 3. Module 4 was described as being more tiring and Module 5 as having an excessive amount of texts. However, participants suggested Module 6 should have a greater number of clinical cases to illustrate the multidisciplinary treatment.

Despite the large number of positive aspects in the open questions, it is important to emphasize that the criticisms and suggestions revealed the peculiarities and needs of each module, important information that will serve to guide the improvement of the course content for future applications since the highest percentage of criticisms was in relation to the excessive amount of content in some modules and very large texts, which was detrimental to the learning process. According to Zen-Mascarenhas and Cassiani (2001), the evaluation of the educational virtual environment is very important as it aims to ensure that the proposed objectives and goals could be achieved and that the material reached its purpose.

Additionally, there were no statistically significant differences between the modules with respect to contribution for the training, quality of the content presented, quality of the illustrations presented and access and navigation (Table 3). Furthermore, no differences were found between the modules in relation to the amount of available content and as to the level of complexity of the displayed contents about dentistry and speech pathology (Table 4 and 5).

With the evaluation of the course content by specialists, it was possible to verify that this material is appropriate to the target public; it discusses the content, considering the different learning strategies, possibilities and intelligence; it has simple, clear and objective language, without errors and according to the current grammatical rules; and it also respects the hierarchy for learning based on integrated knowledge and respecting stages. All these main concepts cited by the evaluators are corroborated by Aretio (1999), according to whom, in the distance learning course, the didactic material plays an important role, assuming the function of informing, motivating, and controlling. It should be able to fill the course objectives, have clear and well defined content, have a modular structure to facilitate the understanding of the theme, have vocabulary according to the level of the target public, and use audio resources, videos, and/or images whenever possible. Thus, the "Interdisciplinary Course in Speech Pathology and Dentistry" can be considered appropriate for distance learning programs or as a complementary material in formal education programs.

\section{Conclusion}

The present study evaluated the effectiveness of a distance course for the purpose of interdisciplinary continuing education in speech pathology and dentistry, finding that, based on the results, the distance course was effective for interdisciplinary training in both undergraduate courses.

The resources provided by the platform chosen to be used in this study (Moodle) fulfilled the needs required. Although some specialists found some difficulties in accessing some videos, the students did not report any criticism regarding the virtual environment. In addition, the users' sat- 
isfaction degree as to the access and navigation on the virtual learning environment varied between excellent, very good, and good, proving it to be an adequate tool for students.

In this study, it was possible to find a statistically significant difference between the evaluations applied to the students before and after the course, demonstrating this material's effectiveness as a training tool. Students who participated in this study showed satisfaction regarding the quality of the course in general, as well as the use of distance learning.

Despite the high number of positive aspects observed in the open questions, the criticisms and suggestions were much valued as they reveal each module particularities and needs, important information that will serve to guide the improvement of the course content for future applications. Most criticisms were about the excessive quantity, which hinders the learning process.

The content evaluation carried out by the specialists enabled us to verify that this material is adequate to the target public; it approaches the content, taking into account different strategies, possibilities and learning intelligences; it has simple, objective and clear language; it has no errors, follows the current grammar rules and respects the hierarchy for learning based on the integrated knowledge and its respective stages.

The results showed the course needs to be improved, but it was considered adequate to the use in programs of Distance Learning or as a complementary material in formal learning programs. The information obtained also contributed to the development of strategies and methodology of interdisciplinary teaching in fields that are complimentary in the speech pathology and/or dentistry training. Thus, the distance learning course was effective for the purposes of Speech Pathology and Dentistry interdisciplinary training.

It is worth considering that the study had limitations. The small sample size allowed us to conclude that the results we found are true for the population in question only. Another important limitation was the lack of similar studies that could guide the methodology to be applied in a better way.

From the evaluation process carried out in this research, it will be possible to improve the interdisciplinary course, enabling its application/offering to the target public, besides contributing with the methodological design of future researches that will study the programs and the application of distance learning courses.

At the same time, the study also shows the importance of the interdisciplinary, or even transdisciplinary, perspective to be worked with Distance Learning, that is, the participation of many other professionals (health field, information and technology, pedagogues, designers) interacting and working in a team will provide a greater quality didactic material, a complete virtual environment and the development of a humanized professional.

\section{Conflict of interest}

The authors declare there is no conflict of interest.

\section{Acknowledgements}

We appreciate the contribution of Prof. Dr. Heitor Honório and Prof. André Luis Porporatti with the statistical tests applied to this study. 


\section{References}

Amaral, E.C., Bacha, S.M.C., Ghersel, E.L.A., \& Rodrigues, P.M.I. (2006). Interrelation between odontology and speech- language pathology in orofacial myology. Revista CEFAC: Speech, Language, Hearing Sciences and Education Journal, 8(3), 337-351.

Aretio, L.G. (1999). Historia de la educación a distancia. Revista Iberoamericana de Educación a Distancia, 2(1), 11-40.

Aretio, L.G. (2001). La educación a distancia. De la teoría a la práctica. Barcelona: Editorial Ariel.

Benkert, K. K. (1997). The effectiveness of orofacial myofunctional therapy in improving dental occlusion. The International Journal of Orofacial Myology, 23, 35-46.

Blasca, W. Q., \& Bevilacqua, M. C. (2003). Multimídea como uma nova proposta de ensino da audiologia. Salusvita, 25(3), 133-125.

Blasca, W. Q., Maximino, L. P., Galdino, D. G., Campos, K., \& Picolini, M. M. (2010). Novas tecnologias educacionais no ensino da audiologia. Revista CEFAC: Speech, Language, Hearing Sciences and Education Journal, 12(6),1017-1024.

Bollela, V. R., Grec, W., \& Matias, A. A. (2009). Shortening distances: A Moodle platform supports programme evaluation in internship. Medical Education, 43(11), 1114-1115.

Broudo, M., \& Walsh, C. (2002). MEDICOL: Online learning in medicine and dentistry. Academic Medicine, 77(9), 926-927.

Campbell, M., Gibson, W., Hall, A., Richards, D., \& Callery, P. (2008). Online vs. face-to-face discussion in a Web-based research methods course for postgraduate nursing students: A quasi-experimental study. International Journal of Nursing Studies, 45(5), 750-759.

Cartes-Velasquez, R., \& Bustos-Leal, A. (2012). Teleodontología: Conceptos, experiencias y proyecciones. Odontoestomatologia, 14(20), 17-25.

Conselho Federal de Fonoaudiologia. (2006). RESOLUÇÃO CFFa n ${ }^{\circ}$ 320, de 17 de fevereiro de 2006. Dispõe sobre as especialidades reconhecidas pelo Conselho Federal de Fonoaudiologia, e dá outras providências. Retrieved from http://www.fonoaudiologia.org.br/legislacaoPDF/Res\%20320-06\%20\%20Especialidades.pdf

Dias, B. K. P., \& Cardoso, M. C. A. F. (2009). Deglutition function characteristics in an institutionalized elderly group. Estudos interdisciplinares sobre o envelhecimento, 14(1), 107-124.

Eskenazi, E. S., Martins, M. A., \& Ferreira, M., Jr. (2013). Tele-educação e monitoria ativa no ensino da saúde bucal a estudantes de medicina. Revista Brasileira de Educação Médica, 37(2), 235-244.

Edwards, P. A. (2005). Impact of technology on the content and nature of teaching and learning. Nursing Education Perspectives, 26(6), 344-347.

Gadbury-Amyot, C. C., Singh, A. H., \& Overman, P. R. (2013). Teaching with technology: learning outcomes for a combined dental and dental hygiene online hybrid oral histology course. Journal of Dental Education, 77(6), 732-743.

Gardella, J. L., Guarin, J. F., \& Vive, J. (2003). La metodología de la educación a distancia una herramienta en neurocirugía. Revista Argentina de Neurocirurgia, 17(2), 81-84.

Hersh, W. R., Junium, K., Mailhot, M., \& Tidmarsh, P. (2001). Implementation and evaluation of a medical informatics distance education program. Journal of the American Medical Informatics Association, $8(6), 570-584$.

Holtslander, L. F., Racine, L., Furniss, S., Burles, M., \& Turner, H. (2012). Developing and piloting an online graduate nursing course focused on experiential learning of qualitative research methods. Journal of Nursing Education, 51(6), 345-348. 
Inglês, K., Rojeski, T., \& Branham, K. (2000). Adquirir habilidades de aconselhamento, em meados de carreira: Resultados de um curso de educação a distância para a prática de fonoaudiólogos. Journal of American Academy of Audiolology, 11(2), 84-90.

Jorge, T. M., Duque, C., Berretin-Félix, G., Costa, B., \& Gomide, M. R. (2002). Oral habits: Interactions between pediatric dentistry and speech therapy. Jornal Brasileiro de Odontopediatria \& Odontologia do Bebê, 5(26), 342-350.

Kemczinski, A., Bringhenti, I., Castro, J. E. E., \& Heinneck, L. F .M. (2000). O desempenho e a satisfação discente em um modelo de ensino-aprendizagem semi-presencial. COBENGE [periódicos na Internet]. Retrieved 17 November 2012 from http://www.abenge.org.br/CobengeAnteriores/2000/artigos/477.PDF

Lieberth, A. K., \& Martin, D. R. (2005). The instructional effectiveness of a web-based audiometry simulator. Journal of the American Academy of Audiology, 16(2), 79-84.

Llambí, L., Margolis, A., Toews, J., Dapueto, J., Esteves, E., Martínez, E., et al. (2008). Distance education for physicians: Adaptation of a Canadian experience to Uruguay. The Journal of Continuing Education in the Health Professions, 28(2), 79-85.

Martins, J. G., \& Campestrini, B. B. (2004). Ambiente virtual de aprendizagem favorecendo o processo ensino-aprendizagem em disciplinas na modalidade de educação à distância no ensino superior. In Proceedings of $11^{\circ}$ Congresso Internacional de Educação a Distância; Salvador, Brasil. Retrieved 17 November 2012 from http://www.abed.org.br/congresso2004/por/pdf/072-TCC2.pdf

Masotti, A. S., Jardim. J. J., Oshima, H. M. S., \& Pacheco, J. F. M. (2002). Ensino a distância em Odontologia via Internet: O que está sendo produzido no Brasil. Revista Odonto Ciência, 17(35), 96102.

Mattheos, N., Nattestad, A., Schittek, M., \& Attström, R. (2001). A virtual classroom for undergraduate periodontology: A pilot study. European Journal of Dental Education, 5(4), 139-147.

Nobre, D. G., Gushiken, F. T., Periotto, M. C., \& Araújo, R. H. (2004). Integration between Phonoaudiology and Dentistry in mouth breathers: Relation with Angle Class II malocclusion and treatment. Revista Paulista de Odontologia, 26(2), 4-11.

Olival, A. R. B., Curvino, M., Faria, M., \& Groisman, S. (2008). New horizons in dentistry: Teledentistry. PerioNews, 2(4), 311-315.

Pinto, A., Selvaggi, S., Sicignano, G., Vollono, E., Lervolino, L., Amato, F., et al. (2008). E-learning tools for education: regulatory aspects, current applications in radiology and future prospects. La Radilogia Medica, 113(1), 144-157.

Rafiq, A., \& Merrell, R. C. (2005). Telemedicine for access to quality care on medical practice and continuing medical education in a global arena. The Journal of Continuing Education in the Health Professions, 25(1), 34-42.

Ribeiro, M. A. S., \& Lopes, M. H. B. M. (2006). Desenvolvimento, aplicação e avaliação de um curso à distância sobre tratamento de feridas. Revista Latino-Americana de Enfermagem, 14(1), 77-84.

Roine, R., Ohinmaa, A., \& Hailey, D. (2001). Assessing telemedicine: A systematic review of the literature. Canadian Medical Association Journal, 165(6), 765-771.

Shaikh, N., Lehmann, C. U., Kaleida, P. H., \& Cohen, B. A. (2008). Efficacy and feasibility of teledermatology for paediatric medical education. Journal of Telemedicine and Telecare, 14(4), 204-207.

Silva, T. R., \& Canto, G. L. (2014). Dentistry-speech integration: The importance of interdisciplinary teams formation. Revista CEFAC: Speech, Language, Hearing Sciences and Education Journal, 16(2), 598603.

Skelton-Macedo, M. C., Basilio, C. C., Alves, N. C. C., Marques, V. P., Menéndez-Casillero, M. E., \& Alves, R. J. C. (2007). Endodontia na graduação com ensino presencial e suporte a distância: motivacional ao estudo individual. [Endodontics at the undergraduate level with presence teaching and distance support: a motivational strategy for individual study.] Revista ABENO, 7(1), 68-75. 
Distance learning: Effectiveness of an interdisciplinary course in speech pathology and dentistry

Smythe, G., \& Hughes, D. (2008). Self-directed learning in gross human anatomy: Assessment outcomes and student perceptions. Anatomic Sciences Education, 1, 145-153.

Soirefmann, M., Blom, M. B., Leopoldo, L., \& Cestari, F. T. (2008). Telemedicina: Uma revisão da literatura. Revista dos Hospitais de Clínicas de Porto Alegre, 28(2), 116-119.

Spinardi, A. C. (2009). Telefonoaudiologia: desenvolvimento e avaliação do CDROM "Procedimentos Terapêuticos nos Transtornos Fonológicos". Bauru. Dissertation [Master's Thesis in Speech Pathology and Audiology] - Bauru School of Dentistry, University of São Paulo. Retrieved from http://www.teses.usp.br/teses/disponiveis/25/25143/tde-04112009-162147/

Spinardi, A. C., Blasca, W. Q., Wen, C. L., \& Maximino, L. P. (2009). Telehealth in speech-language pathology and hearing: Science and technology. Pró-Fono Revista de Atualização Científica, 21(3), 249254.

Telles Filho, P. C., \& Cassiani, S. H. (2008). Creation and evaluation cycle of a distance module for nursing undergraduates, named "medication administration". Revista Latino-Americana de Enfermagem, $16(1), 78-85$.

VanLue, M., Cox, K. M., Wade, J. M., Tapp, K., Linville, R., Cosmato, C., et al. (2007). Development of a microportable imaging system for otoscopy and nasoendoscopy evaluations. The Cleft PalateCraniofac Journal, 44(2), 121-125.

Verrastro, A. P., Tashima, A. Y., Ideriha, P. N., Stefani, F. M., Rodrigues, C. R. M. D., \& Wanderley, M. T. (2009). Occlusal and oral myofunctional characteristics of children treated in Pediatric Dentistry Clinic, School of Dentistry USP. Journal of the Health Sciences Institute, 27(4).

Vieira, M. M. R. M., Berretin-Felix, G., \& Brasolotto, A. G. (2009). The Virtual Man Project's CD-ROM "Voice Assessment: Speech-Language Pathology and Audiology \& Medicine", Vol 1. Journal of Applied Oral Science, 17, 43-49.

Vucković, I., Dilberović, F., Kapur, E., Voljevica, A., Bilalović, N., \& Selak, I. (2003). The principles of telemedicine in practice. Bosnian Journal of Basic Medical Sciences, 3(4), 54-60.

Xelegati, R., \& Évora, Y. D. (2011). Development of a virtual learning environment addressing adverse events in nursing. Revista Latino-Americana de Enfermagem, 19(5), 1181-1187.

Yamaguchi, H., \& Sueishi, K. (2003). Malocclusion associated with abnormal posture. The Bulletin of Tokyo Dental College, 44(2), 43-54.

Zen-Mascarenhas, S. H., \& Cassiani, S. H. B. (2001). Desenvolvimento e avaliação de um software educacional para o ensino de enfermagem pediátrica. Revista Latino-Americana de Enfermagem, 9 , 13-8. 


\section{Appendix Questionnaire of Evaluation of the Scientific Content}

1- Regarding the contribution to your training, the module can be considered:
( ) Excellent
( ) Very good
( ) Good
() Regular
( ) $\mathrm{Bad}$

2- The quality of the contents presented in the module can be considered:
() Excellent
( ) Very good
( ) Good
( ) Regular
( ) $\mathrm{Bad}$

3- The quality of the illustrations presented in the module can be considered:
( ) Excellent
( ) Very good
( ) Good
( ) Regular
() $\mathrm{Bad}$

4- The quantity of contents presented in the module can be considered:

() Insufficient

() Sufficient

() Excessive

5- The level of complexity of the dentistry content presented can be considered:

( ) Little complex

( ) Adequate

( ) Very complex

6- The level of complexity of the speech pathology content presented can be considered:

( ) Little complex

( ) Adequate

( ) Very complex

7- As to the access and navigation in the virtual learning environment, it can be considered:

( ) Excellent

( ) Very good

( ) Good

( ) Regular

( ) $\mathrm{Bad}$

8- Make criticisms, suggestions and / or comments about the module you just took. 


\section{Biographies}

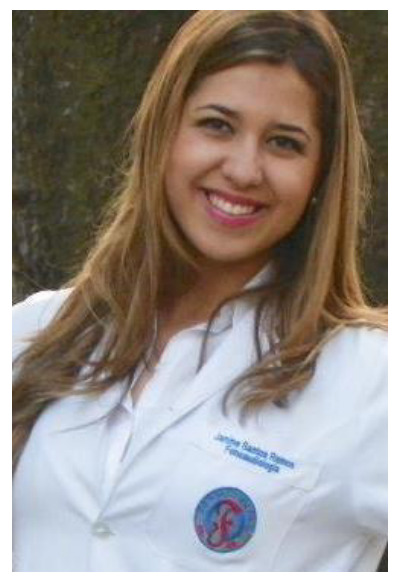

Janine Santos Ramos graduated in Speech Pathology from the University of São Paulo (2012), specialization in Voice by Voice Studies Center (2015) and Master of Science degree, concentration area: Processes and Communication Disorders, Bauru School of Dentistry University of São Paulo (2015). She developed research on orofacial myology and telehealth during graduation. Currently, she is an audiology substitute professor in the graduate course of Speech Therapy of the Federal University of Santa Catarina (UFSC).

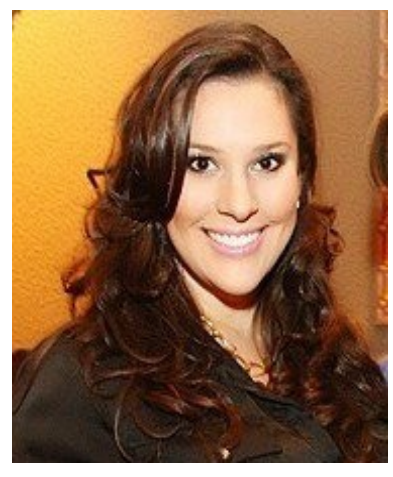

Leticia Korb da Silva graduated in Speech Pathology from the Itajaí Valley University (2010), upgrading in orofacial myology by CEFAC (2010) and Master of Science degree from Bauru School of Dentistry, University of São Paulo-USP (2013). Currently, she is a PhD student at Bauru School of Dentistry, USP. She developed research regarding orofacial myology during graduation and post-graduation. Her main activity is in dental cases, which involve orthodontic treatment, orthognathic surgery, temporomandibular disorders and oral rehabilitation. Recently (2014), she concluded an update in Occlusion, TMD and Orofacial Pain by the Institute of Dental Education of Bauru (IEOBauru).

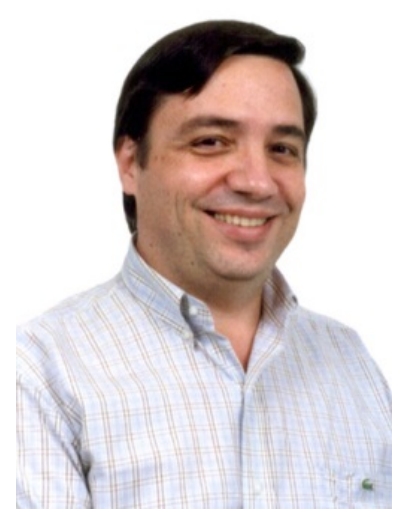

Arnaldo Pinzan graduated in Dentistry from the University of São Paulo (1974), Master's degree in Dentistry (Orthodontics) from the University of São Paulo (1978) and a PhD degree in Dentistry (Prosthodontics), University of São Paulo (1982). He is currently an Associate Professor level III of the University of São Paulo. He is a reviewer of the Journal of Post-Graduation of FOUSP, a reviewer of the Brazilian Oral Research Journal and the Virtual Magazine of Brazilian Academy of Dentistry. He is also a member of the editorial board of the Orto Science. 

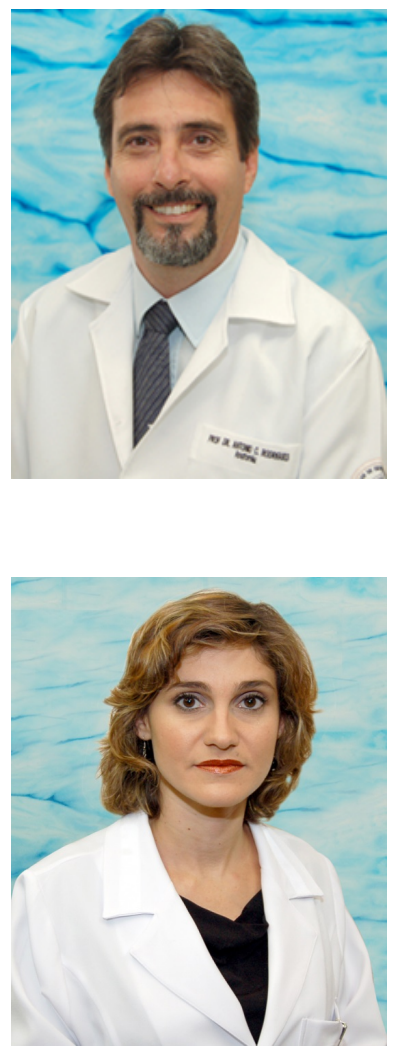

Antonio de Castro Rodrigues graduated in Biology from the Universidade do Sagrado Coração (1981- Bauru), Master (1987) and PhD (1992) degree in Anatomy, Universidade Estadual Paulista Julio de Mesquita Filho of Botucatu-São Paulo. Postdoctoral degree from the University of Copenhgen / Denmark (1995) and Full Professor at Universidade Estadual Paulista Julio de Mesquita Filho (Unesp / Botucatu) since 1998. He is currently an Associate Professor at Bauru School of dentistry- University of São Paulo-USP, advisor of the graduation program in Oral Biology at FOB / USP (2014), and regional Delegate of the BSA (Brazilian Society of Anatomy) of the Southeast of Brazil.

Giédre Berretin-Felix graduated in Speech Pathology, Bauru School of Dentistry (1996), master's degree in dentistry from the University of Campinas (1999), PhD in Pathophysiology in Clinical Medicine from the Universidade Estadual Paulista Julio de Mesquita Filho (2005) and postdoctoral degree in swallowing disorders from the University of Florida (2010). She is currently an Associate Professor of the Department of Speech Pathology, Bauru School of Dentistry, University of São Paulo. She is a tutor from Tutorial Education Program in Speech, and an advisor of the Graduation Program in Speech, FOB / USP. She is the coordinator of the Department of Orofacial Myology of the Brazilian Society of Speech. 